(2011) 19 IIUMLJ 243

\title{
THE DECISION BY A JUDGE ON THE BASIS OF HIS PERSONAL KNOWLEDGE
}

\author{
Shaukat Hayat
}

\begin{abstract}
According to some muslim jurists the decision by a judge based on his personal knowledge is one of the admissible modes of proof. The personal knowledge of a judge here means the judge who is an eyewitness to a fact in issue of a case filed in his court for decision. Should he decide on the basis of his personal knowledge or should he decide on the basis of the statements of the evidence which is contrary to his personal knowledge? Muslim jurists of the different schools of thought have a consensus on the view that a judge can validly decide about the credibility or otherwise of a witness on the basis of his personal knowledge. Two groups of muslim jurists have differing opinion as to whether a judge can validly decide cases on the basis of his personal knowledge. The paper examines the opinion of both groups in the light of their arguments from Qur'an, Sunnah and other sources of Islamic Law. The validity of both schools are discussed with preference of one of them as most suitable for application in Muslim countries.
\end{abstract}

Mr. Shaukat Hayat is an Assistant Professor of Law in the Shari'ah Academy, International Islamic University, Islamabad, Pakistan. 
Keywords: Islamic Law, Islamic procedural law, Islamic law of evidence, personal knowledge of a judge.

\title{
KEPUTUSAN HAKIM ATAS DASAR PENGETAHUAN PERIBADINYA
}

\begin{abstract}
ABSTRAK
Menurut sebahagian fuqaha, keputusan seorang hakim berdasarkan pengetahuan peribadinya adalah salah satu cara pembuktian boleh terima. Pengetahuan peribadi seorang hakim bermaksud hakim tersebut merupakan saksi kepada satu fakta dalam isu sebuah kes yang telah difailkan di mahkamahnya untuk diputuskan. Adakah beliau sepatutnya memutuskan atas dasar pengetahuan peribadinya atau atas dasar pernyataan keterangan yang bertentangan dengan pengetahuan peribadinya. Fuqaha dari mazhab berlainan mencapai kata sepakat bahawa seorang hakim boleh, dengan sah, memutuskan tentang kebolehpercayaan atau sebaliknya seorang saksi atas dasar pengetahuan peribadinya. Dua kumpulan fuqaha mempunyai pendapat berbeza tentang sama ada seorang hakim boleh, dengan sah, memutuskan kes atas dasar pendapat peribadinya. Makalah ini meneliti pendapat kedua-dua kumpulan berdasarkan hujahan mereka daripada al-Quran, Sunnah dan sumber lain undang-undang Islam. Keabsahan kedua-dua aliran ini dibincangkan dengan satu daripadanya dipilih sebagai paling sesuai untuk diterimapakai di negara-negara Muslim.
\end{abstract}

Kata kunci: undang-undang Islam, undang-undang prosedur Islam, undang-undang keterangan Islam, pengetahuan peribadi hakim. 


\section{INTRODUCTION}

To some of Muslim jurists the decision by a judge on the basis of his personal knowledge about the facts of the case heard by him is one of the admissible modes of proof. The personal knowledge of a judge here means the judge who is an eyewitness to a fact in issue of a case filed in his court for decision.

The example of such a situation is the case where a judge has seen "A" murdering "B." The case of murder is filed in his court for decision in which " $\mathrm{C}$ " is accused of murdering "B." The witnesses are testifying that they have seen " $\mathrm{C}$ " murdering "B while the deciding judge has seen "A" murdering "B."

In such a situation the judge has a choice of deciding the case on the basis of his personal knowledge or he could decide it on the basis of the statements of the evidence of the witnesses, contrary to his personal knowledge.

Muslim jurists from different schools of thought have formed a consensus on the view that a judge can validly decide about the credibility or otherwise of a witness on the basis of his personal knowledge. ${ }^{1}$ As far as the question whether a judge can validly decide cases on the basis of his personal knowledge is concerned, Muslim jurists are divided in to the following two groups:

\section{THE JURISTS WHO ARE IN FAVOUR OF THE DECISION BY A JUDGE ON THE BASIS OF HIS PERSONAL KNOWLEDGE}

The Jurists of the Hanafî school of thought, some of the Mâlikî jurists, Imâm Shâfi ‘î, Imâm Ahmad bin Hanbal and Imâm Ibn Hazm alZahirî are in favour of judgment by a judge on the basis of his personal knowledge. These jurists are of the view that the judgment

1 Moḥammad Ibn ‘Âbidin, Radd al-Muhtâr, 5:439, Ibrâhîm Ibn Farḥ̂n, Tabșirat al-Hukkâm, 1:22, Abû al Ḥassan al-Mâwardî, Adab al-Qaḍ̂, 2:369, Moḥammad Ibn Taymîyah, al-Muharar Fi al-Fiqh, (Egypt: Mațb‘at al-Sunnah al-Muḥmmadîyyah, 1369 A.H) 2:2167. 
of a judge who decides a case on the basis of his personal knowledge of the facts of the case, is a valid and enforceable judgment. ${ }^{2}$

In this respect Imâm Ibn Hazm al-Zahirî has gone further to postulate that it is obligatory upon a judge to decide on the basis of his personal knowledge about the facts of the case heard by him. The Imâm is of the view that the personal knowledge of a judge is the most authentic form of evidence. He further says that the authenticity of testimony, admission and confession of a party comes after the personal knowledge of a judge. ${ }^{3}$

These jurists support their view with reference to the following arguments:

a) Allah (سبحاندوتعالى) ${ }^{\text {sa } y s ~ i n ~ t h e ~ H o l y ~ Q u r ' a ̂ n: ~}$

"O ye who believe! Stand out firmly for justice, as
witnesses to Allah, even as against yourselves, or
your parents, or your kin, and whether it be (against)
rich or poor for Allah can best protect both."4

These jurists, while supporting their opinion, argue that in the above quoted verse of the Holy Qur'ân, Allah has demanded the believers to do justice and it is injustice if an oppressor is set free inspite of his oppression. They further argue that if a judge is prevented from deciding on the basis of his personal knowledge it will amount to recognition and support of oppression done by the defendant. If, a judge has heard and seen a person divorcing his wife thrice in the absence of any other witness, the deciding judge is forbidden under the Islamic law to order the continuance of conjugal life between such a couple. ${ }^{5}$

The supporters of the view that the decision by a judge on the basis of his personal knowledge is not legitimate have criticized the above mentioned argument. They argue that a judge is bound to

$2 \quad$ Moḥammad Ibn 'Âbidin, al-Muhtâr, 5:439, Mohammad Ibn Juzay, Qâwanîn al-Ahkâm al-Shar îah, (Beirut: Dâr al-'Elm Li alMala'î1979) 322, Imâm al-Shâfi'î, al-Umm, 6:216.

3 Abû Moḥammad ‘Ali Ibn Ḥazm, al-Muhallah, 9:429.

Al-Nisâ': 135.

Abû Moḥammad ‘Ali Ibn Ḥazm, al-Muhallah, 9:429. 
decide for a victim of oppression only in the case where the victim provides proof of the oppression against him. In a case where the victim fails to provide such proof the judge is not allowed to decide the case for the victim because the Holy Prophet has been reported to have said: ${ }^{6}$

"I am a human being like you. When you bring your disputes to me, some of you might be more fluent and cleverer in arguments. I decide on the basis of what I hear from you. Therefore, if I decide the right of a brother of yours in the favour of another he should not take it because that is a piece of fire that I have cut and given to him."7

b) Allah says in the Holy Qur'ân:

"If thou judge, judge in equity between them. For Allah loveth those who judge in equity."

The supporters of the validity of judgment on the basis of the personal knowledge of a judge argue that in this verse also Allah demands the believers to do justice. If a judge himself is a witness of a fact in issue in the case heard by him he must decide such case on the basis of his personal knowledge in consonance with what the administration of justice requires. ${ }^{9}$

c) In another verse of the Holy Qur'ân Allah says:

"And pursue not that of which thou hast no knowledge."10

$6 \quad$ Mohammad Ibn al-Qayyim, al-Ṭuruq al-Hukmîyyah, 220.

7 Mohammad bin Ismâ‘îl al-Bukhârî, Șậịh al-Bukhârî, (with Fatḥ alBârî), (Cairo: al-Matba'at al-Qahirîyah), 13:143, Muslim bin al-Hajjâj, Sahîh Muslim (with Sharḥ al-Nawawî), 12:504.

$8 \quad$ Al-Mâ'idah: 42.

9 Abû al Hassan al-Mâwardî, Adab al-Qaḍ̂, 2:373.

10 Al-Isrâ': 36. 
The reason for making this verse as an argument for the validity of the decision by a judge on the basis of his personal knowledge is that in this verse Allah has commanded the believers not to follow that about which they do not have any knowledge. On the basis of this, the opposite meaning i.e. mafhûm al-mukhâlafah ${ }^{11}$ of this verse is that if someone has knowledge about something he must act upon that. This means that if a judge has personal knowledge about the facts of a case which he decides, he must decide in accordance with his personal knowledge. ${ }^{12}$

d) The Holy Prophet has been reported to have said:

"Whosoever from amongst you sees an evil let him change it with his hand; if he is not able, let him do so with his tongue; if he is not able to, let him change it with his heart, and this is the weakest of emân."13

Imâm Ibn Hazm says that this tradition of the Holy Prophet demands that if a judge has personal knowledge about an evil, that is an oppression, he must decide against such evil on the basis of his personal knowledge and should do justice without waiting for any other proof or evidence. ${ }^{14}$

Imâm Ibn al-Qayyim has opposed Imâm Ibn Hazm in this regard. While criticizing the argument of Imâm Ibn Hazm, he says that the evil mentioned in this tradition is the evil which comes to the notice of the public and not the evil that specifically comes to the notice of a judge. He quotes the example of the case where a judge has heard and seen a person divorcing his wife thrice and such judge decides the case according to his personal knowledge. The Imâm argues that in such a case apparently the judge does not change the evil with good instead he changes the good i.e. continuance of the conjugal relationship between a husband and

11 The "mafhûm al-mukhâlafah" is a term of Islamic Jurisprudence, which means that the opposite meaning of a legal principal can also be applied as an legal principle.

12 Abû al Ḥassan al-Mâwardî, Adab al-Qaḍ̂, 2:373.

13 Muslim bin al-Ḥajjâj, Șahîh Muslim (with Sharh al-Nawawî), 2:22.

14 Abû Mohammad 'Ali Ibn Ḥazm, al-Muhallah, 9:429. 
his wife with an evil, that is, separation between them which is not known to the general public and is known to the judge only.

Imâm Ibn al-Qayyim further says that if judges are allowed to start ordering separation of married couples on the basis of their personal knowledge there will be possibility that they would be blamed for dishonesty in their decisions. Moreover, if the practice is condoned, some judges may start taking revenge from their enemies by abusing their authority. Moreover, there is the probability that such judges would start pronouncing separation between their enemies and their wives. Therefore, judges should not be allowed to decide on the basis of their personal knowledge. ${ }^{15}$

e) Hind bint 'Utbah, the wife of Abû Sufyân once came to the Holy Prophet and said, "O Messenger of Allah! Abû Sufyân is a tight fisted man. He does not give me what is enough for my son and me. I take from him something out of his property without his knowledge. Do I commit a sin?" The Holy Prophet replied, "Take reasonably from his property what is enough for you and your son." 16

The jurists who support the decision by a judge on the basis of his personal knowledge, argue by referring to the above hadith that it is evident that the Holy Prophet decided against Abû Sufyân on the basis of his personal knowledge. According to these jurists the proof of their argument is that the Holy Prophet decided against Abû Sufyân without asking his wife, Hind for providing evidence of her claim. ${ }^{17}$

However, many jurists have criticized this argument by saying that in this event the statement of the Holy Prophet, "Take from his property what is enough for you and your son" is not qadâ, i.e. adjudication, instead it is iftâ' i.e. the delivery of a legal opinion.

\footnotetext{
15 Moḥammad Ibn al-Qayyim, al-Ṭuruq al-Hukmîyyah, 220.

16 Moḥammad bin Ismâ‘îl al-Bukhârî, Sahîh al-Bukhârî, (with Fath alBârî), 13:146, Muslim bin al-Hajjâj, Sahîh Muslim (with Sharh alNawawî), 12:7, Aḥmad al-Bayhaqî, al-Sunan al-Kubrâ, 10:141.

17 Moḥammad Ibn al-Qayyim, al-Ṭuruq al-Hukmîyyah, 229, Ahmad alQarrafî, al-Furûq, 4:25, Moḥammad bin 'Ali al-Shâukânî, Nayl al-Autâr, 8:325.
} 
It means that such a statement was not delivered by the Holy Prophet as a judgment in a litigation but was a statement made when Hind asked a question seeking guidance from the Holy Prophet. ${ }^{18}$

In reply to this criticism, the proponents are of the view that the ruling of the Holy Prophet shows that it was a decision in adjudication because the words used in it are generally used for a judgment and not for iftâ'. The Holy Prophet used the word "Take what is enough for you." The term "take" is used in the Arabic language for command and order. Had it been simply the deliverance of a legal opinion, the Holy Prophet would have said, "You can take" or "There is no harm if you take." The Holy Prophet has used the words, which indicate that the statement was a decision and not the deliverance of a legal opinion. ${ }^{19}$

f) 'Urwah and Mujâhid narrate that a man from Banî Makhzûm came to 'Umar and complained that Abû Sufyân bin Harb has done an injustice to him in the demarcation of land. Upon that "Umar said, "About this I know more than others as when both of us were children we used to play on that land. Bring Abû Sufyân to me." That man went away and brought Abû Sufyân with him. 'Umar asked Abû Sufyân, "O Abû Sufyân take us to such and such place." When they reached that place, "Umar said to Abû Sufyân, "Take this [demarcation] stone and put it there." Abû Sufyân replied, "By God I will never do that." Upon that "Umar said, "By God you will have to do that." Abû Sufyân again said, "By God I will never do that." Thereupon 'Umar raised his flog and said, "Take it and put it there. You are notorious for injustice since the past." Abû Sufyân took the stone and put it at the point where he was ordered. Thereupon 'Umar faced the qiblah" ${ }^{20}$ and said, "O Allah all praise to You that You did

$\overline{18} \quad$ Mohammad Ibn al-Qayyim, al-Ṭuruq al-Hukmîyyah, 229, Ahmad alQarrâfî, al-Furûq, 4:25, Abû al Ḥassan al-Mâwardî, Adab al-Qâḍ̂, 2:312, Moḥmmad 'Ali al-Shâukânî, Nayl al-Autâr, 8:325.

19 Moḥammad bin Ismâ‘îl al-Bukhârî, Sahîh al-Bukhârî, (with Fath alBârî), 13:149, Muslim bin al-Hajjâj, Sahîh Muslim (with Sharh alNawawî), 8:12, Abû al Ḥassan al-Mâwardî, Adab al-Qâdî̀, 2:312.

20 The Qiblah, is the direction that should be faced when a Muslim prays during salâh. 
not give me death till the time You gave me power to overcome the opinion of Abû Sufyân and You made him do so because of his Islamic faith to submit to me." Abû Sufyân also faced the qiblah and said, "O Allah all praise to You that You did not give me death till the time You put in my heart the [teachings] of Islam which caused me to submit to 'Umar."'21

The supporters of the decision by a judge on the basis of his personal knowledge say, that on this occasion 'Umar not only decided against Abû Sufyân on the basis of his personal knowledge about the facts of the case but also executed his verdict. While deciding against Abû Sufyân, 'Umar neither asked the claimant to provide evidence nor did he require him to take oath to affirm the truth of his claim. ${ }^{22}$

g) Sayyidah Fâtima al-Zahrâ' sent someone to Abû Bakr inquiring about her share in the legacy of the Holy Prophet. Abû Bakr replied, "The Holy Prophet had said that we [the Prophets] do not leave legacy. Whatever we leave behind is sadaqah i.e. charity. The family of the Holy Prophet will take benefit of his property but it will not be given in inheritance to them. By God! I will never make any change in the sadaqah of the Holy Prophet and will act upon what the Holy Prophet has acted upon. Abû Bakr then refused to give anything to Sayyidah Fâtima al-Zahrâ' as her share in inheritance. ${ }^{23}$

These jurists support their view that this event is clear proof that a judge can base his judgment on his personal knowledge as Abû

$21 \quad$ Muslim bin al-Ḥajjâj, Sahị̂h Muslim (with Sharh al-Nawawî), 12:76, Aḥmad al-Bayhaqî, al-Sunan al-Kubrâ, 10:143, Sulaymân bin alAsh'ath Abû Dâwûd, Sunan al-Muhtafâ, 7:120.

22 'Abd Allah Ibn Qudâmâh, al-Mughnî, 9:49, Ala al-Dîn Ibn al-Turkamânî, al-Jauhar al-Naqî, 10:143.

23 Muslim bin al-Ḥajjâj, Saḥịh Muslim (with Sharh al-Nawawî), 12:76, Aḥmad al-Bayhaqî, al-Sunan al-Kubrâ, 10:163. 
Bakr decided this case purely on the basis of his personal knowledge about the sayings of the Holy Prophet. ${ }^{24}$

h) The brother of Saîd bin Atwal died and left behind three hundred dirhams. When Saîd bin Atwal wanted to spend that money on the family of his deceased brother, the Holy Prophet said to him, "Your brother was indebted, pay off his debt." Saîd bin Atwal replied, "O Messenger of Allah I have paid all his debts except a debt of two dirhams that belongs to a woman who has no proof of her claim." Thereupon the Holy Prophet said, "Pay her, she is entitled to it." 25

These jurists argue that in this case the Holy Prophet decided in favour of the woman on the basis of his personal knowledge. ${ }^{26}$

i) These jurists also argue that there is consensus among Muslim Jurists on the view that a judge can validly decide about the admissibility or otherwise of a witness on the basis of his personal knowledge. Therefore, it is quite valid for a judge to decide on the basis of his personal knowledge in other matters too. ${ }^{27}$

j) These jurists further argue that since it is valid for a judge to base his judgment on the testimony of others which is in fact a presumption, he should also be free to base his judgment on his own testimony i.e. his personal knowledge which amounts to a conclusive proof..$^{28}$

\footnotetext{
$24 \quad$ Mohammad Ibn al-Qayyim, al-Ṭuruq al-Hukmîyyah, 177.

25 Imâm Aḥmad bin Hanbal, Masnad al-Imâm Aḥmad bin Hanbal, 4:136, Moḥammad bin Yazîd Ibn Mâjah, Sunan Ibn Mâjah, 2:813.

26 Moḥammad Ibn al-Qayyim, al-Turuq al-Hukmîyyah, 176.

27 Abû al Hassan al-Mâwardî, Adab al-Qậ̣̂, 2:375, 'Abd Allah Ibn Qudâmâh, al-Mughnî, 10:49.

28 Moḥammad Ibn Ahmad Ibn Rushd, Bidâyat al-Mujtahid Wa Nihâyat al-Muqtasid, 2:352, Abû al Ḥassan al-Mâwardî, Adab al-Qâdî, 2:374.
} 


\section{The Time and Place of the Knowledge of the Judge}

The jurists who validate the judgment of a judge on the basis of his personal knowledge have differences of opinion among them about the time and place of the knowledge of the judge on which the judgment is based. Imâm Abû Hanîfah is of the view that a judge can decide on the basis of that knowledge which he acquires after the time of his appointment as a judge and within the limits of the territorial jurisdiction of his court only. The Imâm further says that the decision of a judge on the basis of his personal knowledge gained by him before the time of his appointment as a judge and the knowledge gained by him as judge, however, outside the limits of the territorial jurisdiction of his court is not valid. This is because a judge is obliged as well as empowered to administer justice only after he is appointed as a judge. The decision of a judge on the basis of his personal knowledge gained by him before the time of his appointment as judge and the knowledge gained by him outside the limits of the territorial jurisdiction of his court is not valid because during that time he has no authority to administer justice. ${ }^{29}$

Imâm Mohammad and Imâm Abû Yûsuf, do not agree with Imâm Abû Ḥanîfah in this respect. They are of the opinion that there is no difference between the knowledge gained by a judge before his appointment or after his appointment as such. Therefore, a judge can validly make a judgment on the basis of the knowledge gained by him before or after his appointment as a judge.

According to Imâm Moḥammad and Imâm Abû Yûsuf it makes no difference whether such knowledge was acquired by the judge within the territorial jurisdiction of his court or outside such limits. In both the cases, a judge can validly base his judgment on his personal knowledge. ${ }^{30}$

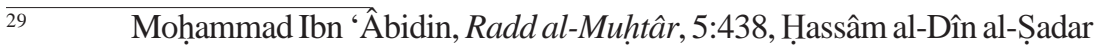
al-Shahîd, Sharh Kitâb Adab al-Qậî̀, 3:101, Ahmad al-Ṭaṭ̂vî, Mukhtasar al-Tatâvî (Cairo: Dâr al-Kitab al-'Arabî, 1370 A.H) 332.

30 'Abd al-Rahmân Shykhzâdah, Majma'al-Anhur, (Egypt: al-Maṭba'atalUthmânîyah,) 3:167, Ḥassâm al-Dîn al-Ṣadar al-Shahîd, Sharh Kitâb Adab al-Qậ̣̂î, 3:101, Moḥammad Ibn ‘Âbidin, Radd al-Muhtâr, 5:439. 


\section{(ii) Matters which a Judge cannot Decide on the Basis of his Personal Knowledge}

Imâm Abû Ḥanîfah, Imâm Moḥammad and Imâm Abû Yûsuf as well as the majority of the Shâfi'î jurists are of the view that a judge can validly base his judgment on his personal knowledge in all the cases involving huqûq al- 'ebâd i.e. the rights of human beings. However, it is not valid for him to decide on the basis of his personal knowledge in matters relating to hudûd. In theft cases, however, a judge can base his judgment on his personal knowledge about the property involved in the theft, however, he cannot decide on the execution of hadd. ${ }^{31}$

In regard to the matters concerning which a judge cannot decide on the basis of his personal knowledge, Imâm Shâfi ‘î has been reported to have held that a judge can base his judgment on his personal knowledge in all matters including hudûd cases. ${ }^{32}$ In this regard Imâm Ibn Ḥam has supported the view of Imâm Shâfi'î. $\mathrm{He}$ is of the opinion that a judge can base his judgment on his personal knowledge in all matters including hudûd. ${ }^{33}$

\section{(iii) Conditions for Validity of Decisions by a Judge on the basis of his Personal Knowledge}

Muslim jurists have prescribed certain conditions for the validity of the decision by a judge on the basis of his personal knowledge. The first condition in is that the judge must make it clear to the party against whom he is deciding that he has based his decision on his personal knowledge. ${ }^{34}$ The second condition is that he must clearly tell the party against whom he is deciding that he

\footnotetext{
31 Moḥammad Ibn 'Âbidin, Radd al-Muhtâr, 5:438, 'Alâ' al-Dîn alSamarqandî, Tuhfat al-Fuqahâ', (Damuscus: Maṭba' at Jami'at Damishq, 1959) 638, Aṭmad al-Haythamî, Tuhfat al-Muhtâj, 10:148, Abû al Hassan al-Mâwardî, Adab al-Qâḍ̣̂, 2:148.

32 Mohammad bin 'Ali al-Shâukânî, Nayl al-Autâr, 8:301.

33 Abû Moḥmmad ‘Ali Ibn Ḥazm, al-Muhallah, 9:426.

34 Abû al Ḥassan al-Mâwardî, Adab al-Qậ̣̂̂, 2:377, Sulayman al-Bejarmî, Hâshîyat al-Bejarmî, 4:353.
} 
himself is the witness to the right of his opponent. ${ }^{35}$ The third condition is that such a judge must be known for his truthfulness, honesty and piousness. The fourth condition is that he must not be notorious for his mistakes and faults. The fifth condition dictates that he must not have committed an offence. ${ }^{36}$

\section{(iv) The Effect of Contradiction between the Knowledge of the Judge and the Evidence}

In regard to the legality of the judgment made by a judge on the basis of his personal knowledge, one of the questions which Muslim jurists have discussed in detail pertains to what a judge should do when the testimony of the witnesses is contrary to his knowledge? Should he decide on the basis of his knowledge, or should he decide on the basis of the available evidence even if such evidence is contrary to his personal knowledge? If a judge has seen a person with his own eyes murdering another and the next day a third person is brought to his court accused of the murder, should he pronounce the death penalty on the innocent accused or should he acquit him on the basis of his personal knowledge?

The eminent Mâlikî jurist, Ibn Rushd in his renowned work, "Bidâyat al-Mujtahid" has discussed this important issue. In this regard, he says that the jurists of all the schools of thought have a consensus on the view that when the testimony of the witnesses is contrary to the personal knowledge of a judge, the judge must not decide the case on the basis of his personal knowledge. ${ }^{37}$

Regarding the effect of the contradiction between the knowledge of the judge and the evidence produced before him, the jurists of the Shâfi'î school of thought are divided into two opinions. The majority is of the view that in such a situation the judge should not decide on the basis of the evidence, because the falsity of such

\footnotetext{
$35 \quad$ Ibid.

36 Badr al-Dîn al- 'Aynî, 'Umdat al-Qârî Sharh Sahîh al-Bukhârî, 24:235, Shams al-Dîn al-Khatîb al-Sharbînî, Mughnî al-Muhtâj, 4:298.

37 Mohammad Ibn Ahmad Ibn Rushd, Bidâyat al-Mujtahid Wa Nihâyat al-Muqtasid, 2:470, Sulay-mân al-Bajî, al-Muntaqa, (Egypt: Mațba'at al-Sa'adah, [n.d]) 5:185.
} 
evidence is clear to him and he himself is the eye witness to the fact in issue. ${ }^{38}$ Some other Shâfi ‘î jurists are of the opinion that in such a situation the judge should decide on the basis of the evidence as evidence is a valid means of the proof of a fact. ${ }^{39}$

From the above opinions it may be concluded that in the case where the testimony of the witnesses is contrary to the personal knowledge of the judge he should not decide the case on the basis of his personal knowledge as the evidence provided is in contradiction with his knowledge. Similarly, he should also not decide on the basis of the evidence the falsity of which is proven to him. According to the Mâlikî jurists, the best course for the judge in such a situation is to transfer the case to the court of another judge and he should himself appear as a witness in the case. Imâm al-Awza'î is also of the view that in such a situation the judge should transfer the case to another court and should appear in such court as a witness. ${ }^{40}$ The above-mentioned views of the jurists seem to be rational because these views are supported by the following events from Islamic history:

a) Two persons brought their dispute to "Umar. One of them said to him, "You will be my witness." Thereupon 'Umar said, "If you wish me to testify for you I will not decide your dispute or I will decide your dispute and will not testify for you." ${ }^{11}$

It appears from the above-mentioned event that "Umar was a witness for those two persons, therefore, he refused to decide their dispute himself on the basis of his personal knowledge. Instead, he proposed that the case should be taken to another judge and if he was sought to decide the dispute himself, he was not ready to function as a judge and as a witness at the same time.

b) Once a person requested qâdî Shurayh to testify for him in his own court. Upon that qâdî Shurayḥ said, "Let us go to the amîr. I will testify for you before him."42

\footnotetext{
38 Abû al Hassan al-Mâwardî, Adab al-Qâḍ̂, 2:378.

39 Sulaymần al-Bajî, al-Muntaqa, 5:185.

40 'Abd Allah al-Jubûrî, Fiqh al-Imâm al-Auzâ 'î, (Bagdad: Maṭba'at alIrshâd, 1978) 3:94.

41 Hassâm al-Dîn al-Șadar al-Shahîd, Sharh Kitâb Adab al-Qâdî, 3:94.

42 Ảbû al Hassan al-Mâwardî, Adab al-Qâdî̀, 2:373.
} 
This event is also an argument against the decision of a judge on the basis of his personal knowledge as qậ̂i Shurayh refused to decide the case on the basis of his personal knowledge and proposed that the case should be filed in the court of amîr so that he could appear in his court as a witness.

The above-mentioned event clearly means that it is not permissible for a judge to decide on the basis of his personal knowledge. Moreover, a judge shall always base his judgment on the available evidence. However, where a judge decides a matter in which he himself is an eye witness and the statements of the witnesses in such case is contrary to the personal knowledge of the judge, he should refer the case to another judge and should appear in his court as a witness.

\section{JURISTS WHO OPPOSE THE DECISION BY A JUDGE ON THE BASIS OF HIS PERSONAL KNOWLEDGE}

Some of Ḥanafî jurists, Imâm Mâlik, some of Shâfi'î, jurists, and some of Hanbalî jurists are of the view that it is not permissible for a judge to decide on the basis of his personal knowledge. In the opinion of these jurists, a judge shall always base his judgment on the evidence provided by the plaintiff and shall not base his judgment on his personal knowledge. ${ }^{43}$

\section{(i) Their Arguments}

These jurists support their view with the following arguments:

a) These verse of the Holy Qur'ân:

"And those who launch a charge against chaste women, and produce not four witnesses [to support

\footnotetext{
43 Moḥammad Ibn ‘Âbidin, Radd al-Muhtâr, 5:439, Imâm Malik Ibn Anas, al-Mudawwanat al-Kubrâ, (Eagypt: Mațba'at al-Sa'adah [n.d]), 5:148, Abû al Hassan al-Mâwardî, Adab al-Qâdî̀, 2:370, 'Abd Allah bin Ahman Ibn Qudamah, al-Mughni, 9:55.
} 
their allegations], flog them with eighty stripes; and reject their evidence ever after: for such men are wicked transgressors." 44

These jurists argue that the requirement of the general meaning of this verse is that the person who charges an unblemished woman with the act of fornication and fails to provide four witnesses on the truth of his accusation should be punished with eighty lashes. If a person accuses a woman with adultery without the requisite number of witnesses, he has to be subjected to the prescribed punishment even if the deciding judge personally knows the truth of the accusation of such person. ${ }^{45}$ According to this view the judge who knows the truth of accusation cannot decide on the basis of his knowledge, instead he is bound to pronounce the punishment on the accused.

b) These jurists also support their view with the following narration of Umm-Salmah:

"Two men who had a dispute relating to inheritance came to the Holy Prophet. I came to know that they had no evidence upon their claims. The Holy Prophet said to them, "You bring your disputes to the Messenger of Allah; while I am a human being, some of you may be more rhetorical in arguments than others. I decide upon what I hear from you. Whosoever is given anything out of his brother's right should not take it because it is a piece of fire which I sever for him [from the fire of Hell]. He will come [on the Day of Judgment] with this fire poking his neck." The men wept upon hearing this and each one of them said, "My right is for my brother." The Holy Prophet said, "Stand up and go to partition the property and follow the right (justice) and each one should absolve the other." 46

This tradition is proof of the view that a judge should base his judgment upon what he hears from the witnesses and not upon

\footnotetext{
$44 \quad$ Al-Nûr: 4.

45 Sulayman al-Bâjî, al-Muntaq, 5:185, Ahmad al-Qarrâfî, al-Furûq, 4:25.

46 'Abd Allah bin Moḥammad bin Abî Shaybah, al-Musannaf, (Riyyadh:

Maktabat al-Rushd, 1409 A.H) 4:541, Sulaymân bin al-Ash'ath Abû Dâwûd, Sunan al-Mustafâ, (Egypt: Mațba‘at al-Sa‘âdah, 1950) 3:410.
} 
what he personally knows about the facts of the matter filed in his court for decision. Therefore, a judgment which has been made by a judge on the basis of his personal knowledge is not a valid judgment. ${ }^{47}$

c) These jurists also support their view about the judgment of a judge on the basis of his personal knowledge with the following tradition:

"Sayyîdah 'Ayishah reports that the Holy Prophet once sent Abû Jaham bin Hudhyfah for the collection of zakât. He injured a person who had refused to pay zakât. The kinsmen of the injured person came to the Holy Prophet and said, "qișâs $s^{48}$ O Messenger of Allah." The Holy Prophet said to them, "This much [money] is for you." However, upon not agreeing on the amount, the Holy Prophet increased it and said to them, "This much [money] is for you." They agreed upon the increased amount. The Holy Prophet said to them, "Should I inform the people that you have agreed." They said, "Yes." Then the Holy Prophet collected the people and said, "These people come to me to recover qisâs. I offered them this much so they agreed." Then the Holy Prophet asked those people, "Did you agree." They said, "No." Upon that the muhâjir companions wanted to attack them, however, the Holy Prophet ordered them to stop. The Holy Prophet again increased the amount and said to them, "Are you agreed now." They said, "Yes." The Holy Prophet said to them, "Should I inform the people that you have agreed." Thereupon they said, "Yes." Then the Holy Prophet again addressed the people, and asked those who wanted the qișâs, "Are you agreed now." Thereupon they said, "Yes." 49

In this case, the relatives of the injured person after agreeing with the Holy Prophet denied their agreement in front of the people. Although the Holy Prophet was well aware about their falseness, however, he did not decide against them on the basis of his personal

\footnotetext{
47 Aḥmad al-Qarrâfî, al-Furûq, 4:44.

48 The punishment of retaliation awarded for the offence of murder.

49 Mohammad bin 'Ali al-Shâukânî, Nayl al-Autâr, 8:297, 'Alî̀' al-Dîn Ibn al-Turkamânî, al-Jauhar al-Naqî, 10:26.
} 
knowledge about their falseness and negotiated the matter with them again and increased the money for them. ${ }^{50}$

d) The following hadith is also presented by these jurists in support of their opinion:

"Jâbir reports that a man came to Ja 'rânah from Hunayn where the Holy Prophet was distributing silver among the people. That person said, "O Muhammad, do justice." The Holy Prophet said to him, "May you die, if I do not do justice then who will do justice. Indeed I will not be successful if I do not do justice." Thereupon "Umar said, O Messenger of Allah let me kill this hypocrite." The Holy Prophet did not allow him to do so and said, "People will say about me that I kill my companions. This man and his friends read the Qur'ân, however, it does not go beyond their throats. Soon they will go out of Islam as an arrow goes out of a bow." 51

These jurists supporting their view with this event say that in this event the Holy Prophet did not order the execution of that apostate on the basis of his personal knowledge although his apostasy was crystal clear to the Holy Prophet. ${ }^{52}$

e) These jurists in support of their viewpoint also refer to a dispute between a man from Hadarmaot and another from Kindah. While deciding the dispute the Holy Prophet said to the Hadramî claimant, "Either your two witnesses or his [defendant's] oath." These jurists say that in this case the Holy Prophet has prescribed the fundamental principles for the decision of a dispute; the claimant bears the burden of proving his claims. Where the plaintiff has no evidence of his claim the defendant shall be asked to take oath on the falseness of the claim of the plaintiff. While prescribing this principle for the decision of a dispute the Holy Prophet has nowhere

\footnotetext{
$50 \quad$ Moḥmmad Ibn Aḥmad Ibn Rushd, Bidâyat al-Mujtahid Wa Nihâyat al-Muqtasid, 2:352, Ahmad al-Qarrâfî, al-Furûq, 4:44, 'Abd Allah Ibn Qudâmâh, al-Mughnî, 8:297.

51 Moḥammad bin 'Ali al-Shâukânî, Nayl al-Autâr, 8:297, Muslim bin alḤajjâj, Sahîhh Muslim (with Sharh al-Nawawî), 8:158, Moḥammad Ibn Mâjah, Sunan Ibn Mâjah, 1:61.

52 Moḥammad Ibn al-Qayyim, al-Ṭuruq al-Hukmîyyah, 214.
} 
referred to the personal knowledge of a judge on the basis of which he can decide the dispute..$^{53}$

This event also clearly shows that the judgment on the basis of the personal knowledge of a judge is not valid. Had it been valid the Holy Prophet would have mentioned it in this case.

f) These jurists also claim that the companions of the Holy Prophet had a consensus on the invalidity of the judgment on the basis of the personal knowledge of a judge. They further say that Abû Bakr, 'Umar, 'Abd al-Raḥman bin 'Awf, Ibn 'Abbas and $\mathrm{Mu}$ 'awiyah have restricted judges from deciding on the basis of their personal knowledge and no one from amongst the companions had ever raised any objection on such restriction. ${ }^{54}$

From the above-mentioned argument, it becomes clear that the companions of the Holy Prophet had a consensus on the invalidity of a judgment on the basis of the personal knowledge of a judge.

g) The logical argument of these jurists is that the only role of a witness in a proceeding is to testify. On the other hand, the only function of a judge is to decide on the basis of such testimony. It means that as a witness has no authority to decide in the same manner a judge has no authority to testify and decide the case on the basis of his personal evidence. Moreover, if a judge is permitted to decide on the basis of his personal knowledge it will mean that as proof, a case pertaining to a right would require only one witness. This is not true as Islamic Law requires the testimony of at least two witnesses. Therefore, based on this argument the decision of a judge on the basis of his personal knowledge is not valid.

Additionally, if the personal knowledge of a judge is considered equal to the evidence of two witnesses, it will mean that a contract of marriage can validly be concluded with the single witness of a judge while it is contrary to the rule that no contract of marriage can be concluded unless it is attested by two witnesses. ${ }^{55}$

\footnotetext{
53 Aḥmad bin 'Ali bin Hajar al-'Asqalânî, Fath al-Bârî, 19:259, Mohammad bin 'Ali al-Shâukânî, Nayl al-Autâr, 8:299.

54 Moḥammad Ibn al-Qayyim, al-Ṭuruq al-Hukmîyyah, 213, Abû Moḥammad 'Ali Ibn Hazm, al-Muhallah, 10:268.

55 Abû̉ al Hassan al-Mâwardî, Adab al-Qâdî̀, 2:373.
} 
h) It is essential that the position of a judge and his integrity should be beyond any doubt or allegation. Since a judge, being a human being, cannot be absolutely objective, he is liable to be exposed to charges of favoritism and dishonesty especially when one of the parties to a dispute is his relative or friend. Therefore, for the protection of the integrity of a judge, it is indispensable that he should not be given the authority to decide cases on the basis of his personal knowledge. This is to save his sacred office from the charges of favoritism and dishonesty. ${ }^{56}$

i) These jurists have further explained their opposition to the decision of a judge on the basis of his personal knowledge arguing that if he is allowed to do so the public will have doubts about his integrity. People will believe that such judge is abusing his authority to decide on the basis of his personal knowledge either to take revenge on his opponents or to benefit his relatives. Therefore, a judge is advised not to decide on the basis of his personal knowledge so that his sanctified office is protected from doubts about the integrity of the judges. ${ }^{57}$

j) A well known companion, 'Ikramah reports that 'Umar once asked "Abd al-Raḥmân bin "Awf, "If you were an amîr and I, as a judge, see a person committing theft or fornication what will be the rule?" "Abd al-Rahmân bin "Auf replied, "Your evidence will be equal to the evidence of an ordinary Muslim." Thereupon "Umar said, "You are right."

This shows that the proper way in an event like this is that the judge should not decide the case himself. Instead, he should transfer the case to another court and should appear in such court as a witness. ${ }^{58}$

k) When the eminent judge, Qâdî Shurayh was once requested by a person to testify for him in a case being heard by Qâdî Shurayh

\footnotetext{
56 Sulayman al-Bâjî̀, al-Muntaq, 5:185, Ahmad al-Qarrâfî, al-Furûq, 4:25.

57 Badr al-Dîn al-'Aynî, 'Umdat al-Qârî Sharh Șậịh al-Bukhârî, 24:249, Moḥammad Ibn Rushd, Bidâyat al-Mujtahid, 2:465.

58 Moḥammad bin Ismâ‘îl al-Bukhârî, Sahị̣̂h al-Bukhârî, (with Fath alBârî̀), 9:212.
} 
himself he said to that person, "Les us go to the Amîr. I will testify for you in his court." ${ }^{59}$ This event clarifies the opinion of the most celebrated judge of the Islamic judicial history, Qâdî Shurayh about the decision of a judge on the basis of his personal knowledge. In this case, Qâdî Shurayh clearly refused to decide a case on the basis of his personal knowledge and proposed that the case should be transferred from his court to the court of the Caliph so that he can appear as a witness there.

\section{THE PAKISTANI PROCEDURAL LAWS ON JUDGMENT BY A JUDGE ON THE BASIS OF HIS PERSONAL KNOWLEDGE}

Under the Code of Criminal Procedure (V of 1898), no Judge or Magistrate is authorized to try any case in which he is personally interested. In this regard, Section 556 of the Code of Criminal Procedure (V of 1898) reads:

"No Judge or Magistrate shall, except with the permission of the Court to which an appeal lies from his Court, try any case to or in which he is a party, or personally interested, and no Judge or Magistrate shall hear an appeal from a judgment or order passed or made by himself.

\section{Explanation:}

A Judge or Magistrate shall not be deemed a party, or personally interested, within the meaning of this section, to or in any case by reason only that he is a Municipal Commissioner or otherwise concerned therein in a public capacity or by reason only that he has viewed the place in which an offence is alleged to have been committed, or any other place in which any other transaction material to the case is alleged to have occurred, and made an inquiry in connection with the case. 


\section{Illustration:}

A, as Collector, upon consideration of information furnished to him, directs the prosecution of B for a breach of the Excise Laws A is disqualified for trying this case as a Magistrate." 60

Moreover, certain judgments of the higher courts have also invalidated judgment made by a judge on the basis of his personal knowledge. In the light of these judgments a judge may not be a judge as well as a witness in the same case. He should either decide on the basis of the available evidence or should transfer the case to another court and appear in that court as a witness.

Where a magistrate who is otherwise competent to try a case, is himself a witness of identification proceedings in the case, the proper course for him is to move the superior court to transfer the case from his file. ${ }^{61}$ Where a magistrate has recorded the statement of an injured person in the belief that he was in imminent danger of death but the man survived, the magistrate would have to appear as witness in the case, therefore, he cannot try the accused himself. ${ }^{62}$ In this regard the Patna High Court has held in Mangni Lal Marwari v. Emperor:

\footnotetext{
"Where a judge is the sole judge of law and fact in a case tried before him, he cannot give evidence before himself, or import matters in his judgment not stated on oath before the court in the presence of the accused. If he does so, he makes himself incompetent to try it." 63
}

Moreover, it is advisable for a magistrate who has recorded the confession or before whom the identification proceedings have taken place to leave the case for some other court to try the accused.

\footnotetext{
60 The Code of Criminal Procedure (V of 1898): Section 556.

61 The Emperor v. Ram Jatna, All India Reporter 1924 All. 185.

62 Gulam Rasool v. Crown, Pakistan Legal Decisions 1951 FC. 62, Kefatullah Pramanik v. The State and Arshad Ali Mondal, Pakistan Legal Decisions 1965 Dacca. 150.

$63 \quad$ Mangni Lal Marwari v. Emperor, All India Reporter 1918 Pat. 373.
} 
In this regard, Mr. Justice Mohammad Shafi held in Gulab Shah v. The State:

"The only question involved in this case is whether the magistrate who records the confession of a certain person is entitled to try the person making the confession? Under Section 556 of the Code of Criminal Procedure, a magistrate is not authorized to try any case in which he is personally interested. The expression 'personally interested' has been interpreted by the different High Courts as meaning not only 'privately interested' but also 'officially interested.' If a magistrate records a confession then he at once becomes at least officially interested in the case because it is to be proved that the confession recorded by him was genuine, true, and it was taken down after observing all the formalities laid down by the law. Apart from this, he is liable to be called as a witness in the case if the accused retracts the confession. I am, consequently, of the opinion that the trial of the accused by the magistrate who recorded the confession is bad in law. It is quashed, and the case is sent back to the District magistrate for re-trial of the accused by a magistrate other than the one who recoded the confession." 64

\section{CONCLUSION}

Today, if a judge is allowed to decide on the basis of his personal knowledge it can give rise to countless problems. In the early days of Islam, judges were God-fearing and were extremely honest. In that age, no judge could be expected to get involved in any sort of unfairness. If the judges of that age would decide on the basis of their personal knowledge such judgments could have been valid, however, in the present age if the judges are allowed to base their

$64 \quad$ Gulab Shah v. The State, Pakistan Legal Decisions 1957 Pesh. 128. 
judgment on their personal knowledge, there is probability of abuse of judicial authority by some judges.

The following statement of Imâm Shâfi ‘î supports the view that if the judges of today are allowed to decide on the basis of their personal knowledge they might abuse their authority:

"Had there not been unfair judges we would have
said that a judge might decide on the basis of his
personal knowledge." 65

If in the age of Imâm Shâfi'î, which is known to be the age of piety and honesty, the judges were expected to get involved in unfairness, the judges of the present day are much more likely to get involved in unprofessional conduct. Therefore, if the present day judges are allowed to decide on the basis of their own knowledge it is almost impossible to prevent them from getting involved in abusing judicial authority.

The eminent Muslim jurist of the eighth century, Imâm Ibn al-Qayyim had forbidden his contemporaries from deciding on the basis of their personal knowledge even if they were truthful in their evidence. In this regard, he has taken a firm stand and has said:

"It is essential to forbid decision by a judge on the basis of his personal know-ledge even if such decision is [legally] allowable." ${ }^{\prime 66}$

In so far as Imâm Abû Hanîfah is support for judgment on the basis of the personal knowledge of a judge, the practice can be supported by the fact that the people of his time were extremely honest. Moreover, Imâm Abû Hanîfah has favoured such judgment with the intention that the rights of people be saved from loss because of unavailability of evidence. According to Imâm Abû Ḥanîfah if the decision of a case is delayed until the appearance of the defendant, there is a possibility that some witnesses may die or migrate to somewhere else. Consequently, the plaintiff may lose his evidence and may not be able to get relief from the court.

\footnotetext{
65 Mohammad bin 'Ali al-Shâukânî, Nayl al-Autâr, 8:288.

66 Mohammad Ibn al-Qayyim, al-Ṭuruq al-Hukmîyyah, 216.
} 
However, if Imâm Abû Ḥanîfah had been alive today, most likely he would have revoked his view and would have never allowed the judges of today to decide on the basis of their personal knowledge. For this reason the later Hanafî jurists declared the judgment on the basis of the personal knowledge of a judge invalid. In this regard the eminent Ḥanafî jurist of a later age, Ibn 'Âbidîn says:

"The basic view of our school of thought is that the judgment on the basis of the personal knowledge of a judge is permissible. However, because of the unfairness of the judges of our age, our verdict is that the judgment on the basis of the personal knowledge of a judge is not valid." 67

Another renowned Hanafî jurist and the author of one of the basic sources of the Hanafî classical literature on law, "al-Ashbâh wa al-Nazâir, Zayn al-'Âbidîn Ibn Nujaym has supported the view of the later Hanafî jurists and has said:

"Our verdict is that in this age the personal knowledge of a judge should not be given any consideration." 68

The later Hanafî jurists discarded the concept of judgment on the basis of the personal knowledge of a judge to the extent that they have even taken it out from the list of methods of evidence. This is the reason that the judgment on the basis of the personal knowledge of a judge has not been mentioned in the means of evidence in the famous codification of Hanafî law, Majalat al-Ahkam al-'Adliyyah. Explaining the reason for this, the eminent Turkish jurist and a commentator on Majalat al-Ahkam al- 'Adliyah, 'Ali Hayder Âfanidî says:

\footnotetext{
67 Moḥammad Ibn 'Âbidin, Radd al-Muhtâr, 5:439, Ibrâhîm Ibn Farhụ̂n, Tabșirat al-Hukkâm, 5:423. 
"It is not valid for a judge of this age to decide on the basis of his personal knowledge. Since the fatwa [of the Hanafî jurists] supports this view, the judgment on the basis of the personal knowledge of a judge has not been mentioned in the means of evidence in the Majalat al-Ahkam al-'Adliyah. If a judge decides on the basis of his personal knowledge about the facts of the case, his decision would be void." 69

Based on the discussion and arguments of the jurists of different schools of thought, it can be concluded that it is no longer valid in any case for a judge today to decide on the basis of his personal knowledge. As a judge, he is legally bound to base his judgments on the available evidence even if such evidence contradicts his personal knowledge. For instance if he has personal knowledge of an offence in a case brought to his court and the evidence tendered is not true, it is advisable that such judge should either decide in accordance with the available evidence or should transfer the case to another court and appear there as a witness. In a murder case witnessed by a judge but decided on contrary evidence of witnesses, it would amount to gross injustice by convicting an innocent person. Therefore, the best course for such a judge is to transfer the case to another court and appear in that court as a witness.

69 'Ali Ḥayder Âfandi, Durrar al-Ahkâm, (Beruit: Maṭba'at al-Nahdah, [n.d]) 4: 482. 